\title{
Integration of 3D printing in computer-aided design and engineering course
}

\author{
Mohd Hairi Mohd Zaman, Mohd Hadri Hafiz Mokhtar, Mohd Faisal Ibrahim, Aqilah Baseri Huddin, \\ Gan Kok Beng \\ Department of Electrical, Electronic and Systems Engineering, Universiti Kebangsaan Malaysia, Malaysia
}

\begin{tabular}{|c|c|}
\hline Article Info & ABSTRACT \\
\hline Article history: & Engineering students at an undergraduate level typically learn the design \\
\hline Received Apr 7, 2020 & $\begin{array}{l}\text { aspect and concept through lectures and practical sessions using computer- } \\
\text { aided software. However, the current computer-aided design and engineering }\end{array}$ \\
\hline Revised Sep 22, 2020 & (CAD/CAE) course did not expose the students to apply and relate the latest \\
\hline Accepted Oct 18, 2020 & $\begin{array}{l}\text { advanced technologies to solve global issues, for instance as listed in the } \\
\text { United Nations Sustainable Development Goals (UN SDG). Therefore, an }\end{array}$ \\
\hline Keywords: & $\begin{array}{l}\text { improved CAD/CAE course taken by the students of the Electrical and } \\
\text { Electronic Engineering Programme in Universiti Kebangsaan Malaysia }\end{array}$ \\
\hline 3D printing & integrates $3 \mathrm{D}$ printing and conduct their project based on UN SDG themes. A \\
\hline Computer-aided design & $\begin{array}{l}\text { tal of } 22 \text { projects was produced, which involves both mechanical and } \\
\text { ectrical design with some of the physical models were } 3 \mathrm{D} \text { printed. Thus, }\end{array}$ \\
\hline Computer-aided engineering & students able to strengthen their understanding of the design concept through \\
\hline Integration & the integration of $3 \mathrm{D}$ printing and simultaneously aware of the current global \\
\hline Physical model & is \\
\hline
\end{tabular}

This is an open access article under the $\underline{C C B Y-S A}$ license.

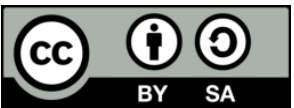

\section{Corresponding Author:}

Mohd Hairi Mohd Zaman,

Department of Electrical, Electronic and Systems Engineering,

Faculty of Engineering and Built Environment,

Universiti Kebangsaan Malaysia,

43600 Bangi, Selangor, Malaysia.

Email: hairizaman@ukm.edu.my

\section{INTRODUCTION}

Producing dynamic graduates who aware of the current global issues and latest technologies is one of the challenges faced by universities and higher education institutes, especially for the engineering field $[1,2]$. Therefore, the engineering design course becomes one of the courses that can realize this challenge. Typically, design course students learn the engineering design aspects through theoretical and conceptual learning in lecture sessions [3-5]. Then, students practice those theories and concepts via laboratory sessions using computer-aided software.

At the same time, all graduated students should be an individual who can adapt to life-long learning upon graduation $[6,7]$. They must be aware and able to tackle problems related to the current global issues as mentioned in 17 Sustainable Development Goals (SDG) stated by United Nations (UN) and ready to apply their engineering knowledge to handle those SDG challenges [8]. Besides, university courses should expose students to the latest technologies such as three-dimensional (3D) printing, which is one of the main pillars in the Fourth Industrial Revolution (IR4.0) [9-14]. Several works integrate this 3D printing technology, especially in science and technology, medical and special education [7, 15-22]. Nowadays, 3D printed parts act as supporting tools for educators [23-28]. For example, medical education courses use 3D printed models in their teaching and learning $(\mathrm{T} \& \mathrm{~L})$ process [29-33]. On the other hand, many works show that the T\&L 
process utilized different kinds of technology to assist the students to enhance their understanding and involvement [34-37].

Therefore, this paper describes a T\&L practice in Universiti Kebangsaan Malaysia (UKM), which integrates 3D printing technology in the engineering design course. In specific, the involved course is the Computer-Aided Design/Computer-Aided Engineering (CAD/CAE) course with a course code of KKKL1103. All first-year undergraduate students of Electrical and Electronic Engineering Programme in Faculty of Engineering and Built Environment, UKM, are compulsory to take this course during the first semester of their four-year study.

\section{RESEARCH METHOD}

In detail, a total of 106 students took the CAD/CAE course in Semester 1, Session 2019/2020, which finally formed 22 groups of students. Each group proposed and designed a project based on one of the 17 UN SDG using their knowledge learned either through lectures or laboratory sessions. This project aims to establish awareness to the students on the current global issues such as social, environmental, and economic problems. Besides, each project combines both mechanical and electrical part designs, even though those students enrolled in the electrical and electronic engineering field. The purpose of this combination is to develop them as multidisciplinary engineers of professionals that able to cope with real-world challenges. Next, each group must produce a physical model using 3D printing technology.

Throughout the project, students use various software to complete their projects. Students used AutoCAD software from Autodesk to design the mechanical parts by drawing several multiview and isometric drawings in 2D and 3D forms. Meanwhile, students also utilized OrCAD software from Cadence to design the electrical and electronic circuits. After that, each group converted the circuitry into the printed circuit board layout to obtain the electrical part dimensions. Then, an assembly drawing combines both mechanical and electrical parts, similar to the manual of electrical and electronic products. Finally, each group printed some mechanical parts from their project using a 3D printer, model Snapmaker 3-in-1, as shown in Figure 1, using SnapmakerJS software.

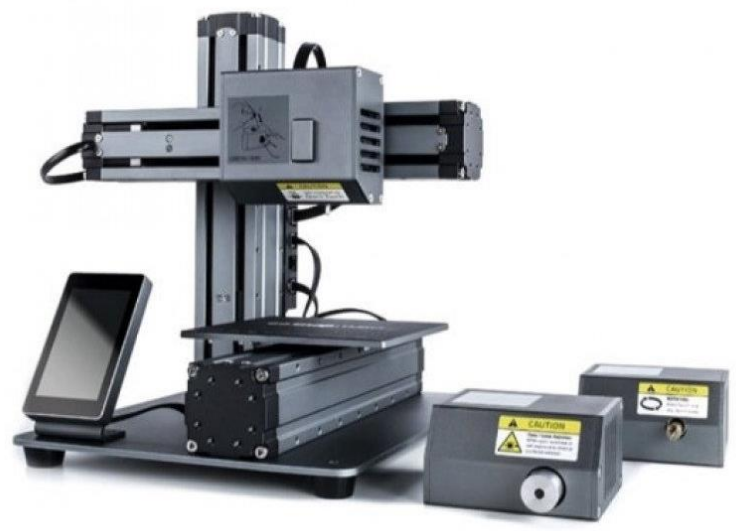

Figure 1. 3D printer model snapmaker 3-in-1

\section{RESULTS AND DISCUSSION}

Overall, a total of 22 projects have been designed by the students based on UN SDG. Table 1 lists all project titles and corresponding UN SDG. UN SDG 6 (clean water and sanitation) is the most selected theme which is $36.4 \%$ from all projects. Meanwhile, UN SDG 4 (quality education) and UN SDG 7 (affordable and clean energy) are the least chosen themes with only one group. This outcome shows that UN SG 6 is the theme that relates directly to the student's current knowledge. This aspect is also important for their life-long learning in the future after graduation $[1,6]$. 
Table 1. List of the project title and theme related to UN SDG

\begin{tabular}{clc}
\hline ti & \multicolumn{1}{c}{ Project title } & UN SDG theme \\
\hline 1 & Thermo hydro-sack & SDG 6 \\
2 & Food waste grinder & SDG 6 \\
3 & Multifunction easy use desk & SDG 9 \\
4 & Heat sensor & SDG 16 \\
5 & Burglar alarm & SDG 16 \\
6 & Turbidity & SDG 6 \\
7 & Foldable trolley & SDG 4 \\
8 & Smart umbrella & SDG 11 \\
9 & Automatic water quality detector & SDG 6 \\
10 & Automatic pharmacy & SDG 3 \\
11 & Resident lift & SDG 11 \\
12 & Health watch & SDG 3 \\
13 & Fingerprint door lock & SDG 16 \\
14 & Portable turbine & SDG 6 \\
15 & Flood detector & SDG 11 \\
16 & Solar-powered water purifier & SDG 6 \\
17 & Water bag & SDG 6 \\
18 & Eco-bin & SDG 11 \\
19 & Piezoelectric tiles power generator & SDG 9 \\
20 & Power plug & SDG 7 \\
21 & Sewage scout & SDG 6 \\
22 & Foldable chair & SDG 3
\end{tabular}

Furthermore, Figure 2(a) shows an example of engineering drawing drawn using AutoCAD software, while Figure 2(b) depicts the actual mechanical part printed using the 3D printer. This type of project, which involves 3D printing prototypes is common in undergraduate study levels [7, 12]. Chong [7] reported $46 \%$ of their project requires students to fabricate actual 3D printing parts. Meanwhile, Poudel [12] showed that students able to write up documentation on their 3D prototype projects. Besides, Figure 3(a) and Figure 3(b) shows another example from the other group. These outcomes prove that the students able to strengthen their understanding of the theory and concept by fabricating some of the mechanical parts in the project using 3D printing technology [3, 24, 25]. Chiu [3] stated that student's creativity increased after learning 3D printing technology.

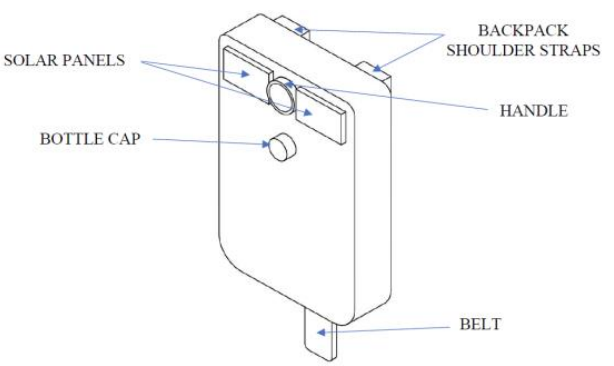

(a) Engineering drawing

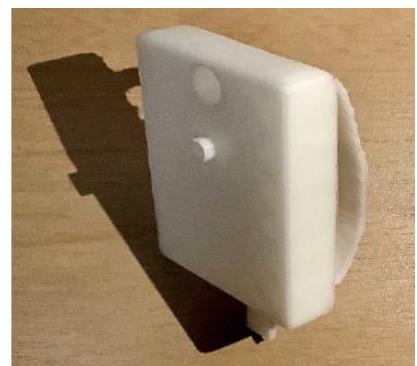

(b) Actual part

Figure 2. The first example of 3D printed parts

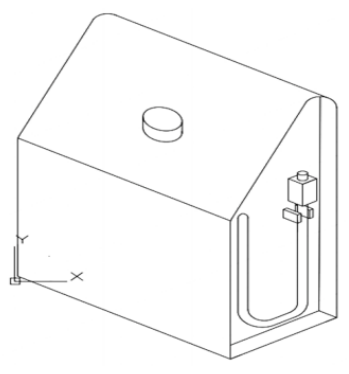

(a) Engineering drawing

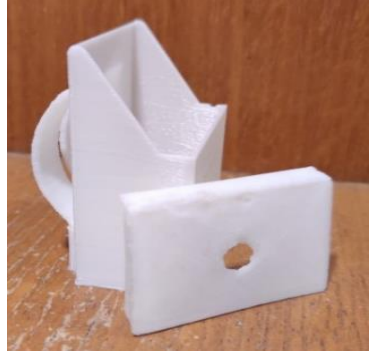

(b) Actual part

Figure 3. The second example of 3D printed parts 


\section{CONCLUSION}

Integration of $3 \mathrm{D}$ printing in the computer-aided design and engineering course able to expose the students to the application of the latest technology, which eventually strengthens their understanding by fabricating the actual part. This experiential learning improves their critical thinking and psychomotor skills. Besides, other engineering courses should integrate other pillars in IR4.0 and UN SDG in the future to enhance student performance and awareness of local and global issues.

\section{ACKNOWLEDGEMENTS}

The authors acknowledge the financial support provided by Universiti Kebangsaan Malaysia through Research Grant no. GUP-2018-103.

\section{REFERENCES}

[1] T. Hadinugrahaningsih, Y. Rahmawati, and A. Ridwan, "Developing 21st Century Skills in Chemistry Classrooms: Opportunities and Challenges of STEAM Integration," in AIP Conference Proceedings, vol. 1868, no. 1, pp. 0300081-0300088, 2017.

[2] J. W. Rojewski and R. B. Hill, "A Framework for 21st-Century Career-Technical and Workforce Education Curricula," Peabody J. Educ., vol. 92, no. 2, pp. 180-191, 2017.

[3] P. H. P. Chiu, K. W. C. Lai, T. K. F. Fan, and S. H. Cheng, "A Pedagogical Model for Introducing 3D Printing Technology in a Freshman Level Course based on a Classic Instructional Design Theory," in 2015 IEEE Frontiers in Education Conference (FIE), pp. 1-6, 2015.

[4] M. A. Kolitsky, "Reshaping Teaching and Learning with 3D Printing Technologies," e-mentor Foundation for the Promotion and Accreditation of Economic Education, vol. 56, no. 4, pp. 84-94, 2014.

[5] A. Mani Paudel, "Realizing Proof of Concept in Machine Design with 3D Printing," in 2015 ASEE Annual Conference \& Exposition, pp. 1-13, 2015.

[6] O. C. Hee, L. L. Ping, A. M. Rizal, T. O. Kowang, and G. C. Fei, "Exploring lifelong learning outcomes among adult learners via goal orientation and information literacy self-efficacy," Int. J. Eval. Res. Educ., vol. 8, no. 4, pp. 616-623, 2019.

[7] S. Chong, G. T. Pan, J. Chin, P. L. Show, T. C. K. Yang, and C. M. Huang, "Integration of 3D Printing and Industry 4.0 into Engineering Teaching," Sustain., vol. 10, no. 11, pp. 1-13, 2018.

[8] United Nations, "Sustainable Development Goals (SDG)," 2019. [Online]. Available: https://sustainabledevelopment.un.org/

[9] J. Alvarez-Cedillo, M. Aguilar-Fernandez, R. Sandoval-Gomez, and T. Alvarez-Sanchez, "Actions to be Taken in Mexico Towards Education 4.0 and Society 5.0," Int. J. Eval. Res. Educ., vol. 8, no. 4, pp. 693-698, 2019.

[10] Ministry of International Trade and Industry, National Policy on Industry 4.0, 2018.

[11] N. Carvalho, O. Chaim, E. Cazarini, and M. Gerolamo, "Manufacturing in the Fourth Industrial Revolution: A Positive Prospect in Sustainable Manufacturing," in Procedia Manufacturing, vol. 21, pp. 671-678, 2018.

[12] M. Poudel and D. Roy, "3D Printing and Technical Communication in a Creative Factory Classroom: A Case Study in Japan," Proc. 2019 7th Int. Conf. Inf. Educ. Technol., pp. 92-99, 2019.

[13] S. Banerjee, C. Carithers, A. Chavan, D. Ramanujan, and K. Ramani, "Toying with Design: Experiencing Design for Rapid Prototyping Using Mini-Fabrication Exercises," Proc. ASME Des. Eng. Tech. Conf., vol. 3, pp. 1-11, 2018.

[14] S. Srivastava and S. Pande, "Pedagogical Evaluation of Mechanical Engineering Education Using Additive Manufacturing," Innovative Design, Analysis and Development Practices in Aerospace and Automotive Engineering (I-DAD 2018), Springer Singapore, pp. 167-172, 2019.

[15] Y. H. Chien, "Developing a Pre-engineering Curriculum for 3D Printing Skills for High School Technology Education," Eurasia J. Math. Sci. Technol. Educ., vol. 13, no. 7, pp. 2941-2958, 2017.

[16] A. Pikkarainen, A. Salminen, and H. Piili, "Creating Learning Environment Connecting Engineering Design and 3D Printing," in Physics Procedia, vol. 89, pp. 122-130, 2017.

[17] E. Buehler, N. Comrie, M. Hofmann, S. McDonald, and A. Hurst, "Investigating the Implications of 3D Printing in Special Education," ACM Trans. Access. Comput., vol. 8, no. 3, pp. 11-28, 2016.

[18] C. Schelly, G. Anzalone, B. Wijnen, and J. M. Pearce, "Open-Source 3-D Printing Technologies for Education: Bringing Additive Manufacturing to the Classroom," J. Vis. Lang. Comput., vol. 28, pp. 226-237, Jun. 2015.

[19] A. Eslahi, D. R. Chadeesingh, C. Foreman, and E. Alpay, "3D Printers in Engineering Education," in Enhancing Student-Centred Teaching in Higher Education, Springer International Publishing, pp. 97-112, 2020.

[20] M. A. Butkus, J. A. Starke, P. Dacunto, and K. Quell, "3D Visualization in Environmental Engineering Design Courses: If the Design Fits, Print it!" in 2016 ASEE Annual Conference \& Exposition, pp. 2-14, 2016.

[21] A. Stangl, J. Kim, and T. Yeh, "3D Printed Tactile Picture Books for Children with Visual Impairments: A Design Probe," IDC '14 Proc. 2014 Conf. Interact. Des. Child., pp. 321-324, 2014.

[22] A. Stangl, C. Lo Hsu, and T. Yeh, "Transcribing Across the Senses: Community Efforts to Create 3D Printable Accessible Tactile Pictures for Young Children with Visual Impairments," ASSETS 2015 - Proc. 17th Int. ACM SIGACCESS Conf. Comput. Access., pp. 127-137, 2015.

[23] A. Stern, Y. Rosenthal, N. Dresler, and D. Ashkenazi, "Additive Manufacturing: An Education Strategy for Engineering Students,” Addit. Manuf., vol. 27, pp. 503-514, May 2019. 
[24] S. Greenhalgh, "The Effects of 3D Printing in Design Thinking and Design Education," J. Eng. Des. Technol., vol. 14, no. 4, pp. 752-769, 2016.

[25] S. Ford and T. Minshall, "Invited Review Article: Where and How 3D Printing is Used in Teaching and Education," Addit. Manuf., vol. 25, pp. 131-150, Jan. 2019.

[26] I. Verner and A. Merksamer, "Digital Design and 3D Printing in Technology Teacher Education," in Procedia CIRP, vol. 36, pp. 182-186, 2015.

[27] J. Loy, "eLearning and eMaking: 3D Printing Blurring the Digital and the Physical," Educ. Sci., vol. 4, no. 1, pp. 108-121, 2014.

[28] I. M. Santos, N. Ali, and S. Areepattamannil, Eds., Interdisciplinary and International Perspectives on 3D Printing in Education. United States of America: IGI Global, 2019.

[29] J. Garcia, Z. L. Yang, R. Mongrain, R. L. Leask, and K. Lachapelle, "3D Printing Materials and their Use in Medical Education: A Review of Current Technology and Trends for the Future," BMJ Simul. Technol. Enhanc. Learn., vol. 4, no. 1, pp. 27-40, 2018.

[30] T. Friedman, M. Michalski, T. R. Goodman, and J. E. Brown, “3D printing from diagnostic images: a radiologist's primer with an emphasis on musculoskeletal imaging - putting the 3D printing of pathology into the hands of every physician,” Skeletal Radiology, Springer Verlag, vol. 45, no. 3, pp. 307-321, 2016.

[31] J. S. Matsumoto, et al., "Three-dimensional physical modeling: Applications and experience at mayo clinic," Radiographics, vol. 35, no. 7, pp. 1965-1988, 2015.

[32] K. M. Ogden, C. Aslan, N. Ordway, D. Diallo, G. Tillapaugh-Fay, and P. Soman, "Factors Affecting Dimensional Accuracy of 3-D Printed Anatomical Structures Derived from CT Data," J. Digit. Imaging, vol. 28, no. 6, pp. 654-663, 2015.

[33] Y. AbouHashem, M. Dayal, S. Savanah, and G. Štrkalj, "The Application of 3D Printing in Anatomy Education," Med. Educ. Online, vol. 20, no. 1, article no. 29847, 2015.

[34] R. K. Dewi, S. Wardani, N. Wijayati, and W. Sumarni, "Demand of ICT-based Chemistry Learning Media in the Disruptive Era," Int. J. Eval. Res. Educ., vol. 8, no. 2, pp. 265-270, 2019.

[35] M. Norhailawati et al., "The Power of Social Networking Sites: Student Involvement Toward Education," Int. J. Eval. Res. Educ., vol. 8, no. 3, pp. 549-556, 2019.

[36] S. Zaheer, S. M. Butt, G. V. Anatolyevna, and H. Salmani, "Do Mobile Technology in the Classroom Really Improve Learning Outcomes?” Int. J. Eval. Res. Educ., vol. 7, no. 3, pp. 188-193, 2018.

[37] L. Menano, P. Fidalgo, I. M. Santos, and J. Thormann, "Integration of 3D Printing in Art Education: A Multidisciplinary Approach,” Comput. Sch., vol. 36, no. 3, pp. 222-236, 2019. 